\title{
Correction to: Quality of life among cancer inpatients 80 years and older: a systematic review
}

Jorunn Drageset ${ }^{1,2^{*}} \mathbb{0}$, Reidun Karin Sandvik', Leslie Sofia Pareja Eide ${ }^{1}$, Gunhild Austrheim ${ }^{1}$, Mary Fox ${ }^{3}$ and Elisabeth Grov Beisland ${ }^{1}$

\section{Correction to: Health Qual Life Outcomes (2021) 19:98} https://doi.org/10.1186/s12955-021-01685-0

The original article [1] contained an error in Affiliation \#3 which has since been corrected.

\footnotetext{
Author details

${ }^{1}$ Faculty of Health and Social Sciences, Western Norway University of Applied Sciences, 5063 Bergen, Norway. ${ }^{2}$ Department of Public Health and Primary Health Care, University of Bergen, Bergen, Norway. ${ }^{3}$ York University, Durham, NC, USA.
}

Published online: 03 September 2021

\section{Reference}

1. Drageset J, et al. Quality of life among cancer inpatients 80 years and older: a systematic review. Health Qual Life Outcomes. 2021;19:98. https://doi.org/10.1186/s12955-021-01685-0.

\section{Publisher's Note}

Springer Nature remains neutral with regard to jurisdictional claims in published maps and institutional affiliations. original author(s) and the source, provide a link to the Creative Commons licence, and indicate if changes were made. The images or other third party material in this article are included in the article's Creative Commons licence, unless indicated otherwise in a credit line to the material. If material is not included in the article's Creative Commons licence and your intended use is not permitted by statutory regulation or exceeds the permitted use, you will need to obtain permission directly from the copyright holder. To view a copy of this licence, visit http://creativecommons.org/licenses/by/4.0/. The Creative Commons Public Domain Dedication waiver (http://creativecommons.org/publicdomain/zero/1.0/) applies to the data made available in this article, unless otherwise stated in a credit line to the data. 